Marquette University

e-Publications@Marquette

English Faculty Research and Publications

English Department

$5-1-2004$

Gothic Opera in Britain and France: Genre, Nationalism, and Trans-Cultural Angst

Diane Hoeveler

Marquette University, diane.hoeveler@marquette.edu

Sarah Davies Cordova

Marquette University

Published version. Romanticism on the Net, Vol. 34-35 (May, 2004). Permalink. (C) 2004 University of Montreal. Used with permission. 


\title{
Gothic Opera in Britain and France: Genre, Nationalism, and Trans-Cultural Angst
}

Diane Long Hoeveler

Marquette University

Sarah Davies Cordova

Marquette University

\begin{abstract}
Rescue operas developed along two somewhat different lines: "tyrant" operas and "humanitarian" operas within the general category of "opera semiseria," or "opéra comique." The first type corresponds to the conservative British "loyalty gothic," with its focus on the trials and tribulations of the aristocracy, while the second type draws upon the Sentimental "virtue in distress" or "woman in jeopardy" genre, with its focus on middle class characters or women as the captured or besieged. The first category emphasized political injustice or abstract questions of law and embodied the threat of tyranny in an evil man who imprisons unjustly a noble character. Etienne Méhul's Euphrosine and H.-M. Berton's Les rigueurs du cloître (both 1790) are typical examples of the genre. "Humanitarian" operas, on the other hand, do not depict a tyrant, but instead portray an individual — usually a woman or a worthy bourgeois — who sacrifices everything in order to correct an injustice or to obtain some person's freedom. Dalayrac's Raoul, Sire de Créqui (1789) or Bouilly's and Cherubini's Les deux journées (1800) are examples, along with Sedaine's pre-1789 works. But why, we might ask, were gothic dramas quickly transformed into gothic operas or what are known now as "rescue operas"? This essay examines the social and political ideologies that are explicit in the major gothic operatic adaptations of the most popular gothic novels of Britain, while at the same time examining British opera's very close connections with French models as well as French adaptations of British cultural works.
\end{abstract}

... Mais ce n'est pas aux orateurs révolutionnaires que les romantiques vont demander des leçons de style, c'est à la Révolution en personne, à ce langage fait Histoire, lequel se signifie par des évènements qui sont des déclarations: La Terreur, on le sait bien, ne fut pas seulement terrible à cause des exécutions, elle le fut parce qu'elle se revendiqua elle-même sous cette forme majuscule, en faisant de la terreur la mesure de l'histoire et le logos des temps modernes.[1]

\section{I: Introduction}


The term "British opera" has often been thought an oxymoron. In fact, as the Italian opera made its way into eighteenth-century London it was greeted by outright hostility and contempt by such intellectuals as Jonathan Swift, Samuel Johnson, and numerous others.[2] As a wholly imported art form, arriving fully developed and with its own conventions set largely in place already, opera somehow had to find a way to adapt to British culture before it could be accepted by the public as a legitimate and viable art and form of entertainment. That opera did survive - and thrive - in late eighteenth and early nineteenth-century Britain is due, we think, not to the quality of the music, most of which is forgettable, but to the power of the genre's ability to translate and stage potent ideological materials in a revolutionary age. And that ideological material—fear of violent revolution and its effects on what had been a stable class system - is largely the same content that was developed in the gothic novels of Horace Walpole, Ann Radcliffe, Matthew Lewis, and Charlotte Dacre, and then in the gothic dramas of such adapters as James Boaden, Henry Siddons, and Lewis. These gothic novels and dramas most frequently took as their subjects the unlawful imprisonments of innocent victims of tyranny, released after heroic efforts by disinherited men who regain their rightful lands and title only after proving their worth. Most of these works read now like wish fulfillment, fairy tales or worse, but they were extremely popular and, as such, deserve our critical attention as important ideological markers for their culture.

Paula Backsheider has suggested that gothic dramas are "the earliest example[s] of what we call mass culture ... an artistic configuration that becomes formulaic and has mass appeal, that engages the attention of a very large, very diverse audience, and that stands up to repetition, not only of new examples of the type but production of individual plays" (150). But why, we might ask, were gothic dramas quickly transformed into gothic operas or what are known now as "rescue operas"? This essay examines the social and political ideologies that are explicit in the major gothic operatic adaptations of the most popular gothic novels of Britain, while at the same time examining British opera's very close connections with French models as well as French adaptations of British cultural works.

What is most curious about all of these works is their use of the theme of escape from unjust imprisonment. In fact, the endlessly repeated motif of imprisonment and escape (from a tunnel, a tower, a labyrinth, a camp of pirates, a boat of kidnappers, etc.) is so pervasive that the modern critic knows that it bears the weight of the opera's ideological meaning. But that is precisely where the confusion begins. Is the capture and escape meant to embody a politically and socially conservative message and a direct warning to the protagonists of the drama, and, by extension, to the audience? Or is the message one of revolution and liberation from tyranny and injustice? When one examines these rescue operas in and of themselves and not simply as inferior productions intended for a mass audience, one can see that each of the operas-in both Britain and France - participates in the ongoing national debate about the proper role of the monarchy, the threat of violent revolution, the shock of sudden class transformation, the anxiety of changing gender roles within the family structure, and, finally, the construction of newly nationalistic countries that seek to justify the means they have each taken to modernize and secularize. 
Jeffrey Cox has observed in relation to romantic drama and the French Revolution, that when history itself becomes theatrical, theatre responds by "translating the representation of revolt from history to myth" (241). With this in mind, we might ask, what ideology undergirds gothic drama and opera? Are they, as Peter Brooks has observed about melodrama, essentially conservative, a means of reinstating social and political order (15), or can they be understood as a species of what Hayden White has called "anarchistic," in that it calls for a dissolution of current institutions in order to reclaim a more humane community that existed sometime in the past (24-5)? "Rescue operas" are not simply a politically conservative discourse system as has generally been argued, but rather they intend to present something like an anarchistic warning by constructing a distant past that the opera reshapes as redeemable through the elimination of corrupt aristocrats. Each opera presents a political and social warning to the monarchy: reform or be overthrown by violence, which certainly would seem to constitute something of an anarchist message. The specter of the French Revolution hangs over each of these works and all of them introduce middle-class characters who embody the best of what Britain and France must become if they are to avoid violent and chaotic fates. The operas clearly are attempting to mediate between classes, races, and genders that saw themselves as being at odds over the shape and power structure of the newly evolving bourgeois society. In fact, the operas, like dramas, actually function as cathartic forms, public rituals in which the middle class haunted itself with its own act of imagined, fantasized revolution, usually depicted as some form of matricide or fratricide in a series of what we might see as social and political morality plays. The middle class audience flocked to these plays that presented its own mythology of origins, its own "Hyperion"-like creation of a new order built on the shorn backs of an aristocracy that quite simply did not deserve to survive.

As Robert Miles has noted, those involved in the invention of the gothic embraced the hieratic function of keeping alive the sacred mementoes of the race. But ideological conservatism intersected with the democratic nature of artistic production for the masses, creating what Foucault has called a site of "power/knowledge" at odds with itself. As a site of opposing strategies, rescue operas became a "hazardous play of dominations" seeking to compose for itself a coherent position amid rapid social, historical, and cultural transformations. It is, according to Miles, in the moments of slippage and discontinuity that the ideological business of the gothic aesthetic is most apparent (32). For him, the gothic aesthetic incorporates an idealized national identity together with a myth of origins (50). This position is very close to that most recently put forward by James Watt in his Contesting the Gothic (1999). For Watt, the 1790s through the early 1800 s were dominated by what he calls the creation of "Loyalist Gothic" romances. He sees these works as reactions to Britain's defeat in America in that they consistently portray a proud heritage of military victory played out within an unambiguous moral and political agenda. Setting their action around besieged castles, these operas present a stratified yet harmonious society, use real historical figures from the British military pantheon (Richard the Lion Hearted was a particular favorite), and consistently depict the defeat of effeminate or foreign villains. Loyalist gothics are structurally bound to depict an act of usurpation which is always corrected, often through the supernatural agency of a ghost (7). We might legitimately ask, however, why 
loyalty gothics would be so popular in a country like France, on the verge of overthrowing its king and establishing a republic? Was the viewing of opera and melodrama in which the rightful heir is rescued from those infinitely lower in rank and honor a form of nostalgic denial? A denial of parricide?

When Handel died in 1759 the Universal Chronicle printed an epitaph that saluted him as a musician "whose compositions were a sentimental language rather than mere sounds; and surpassed the power of words in expressing the various passions of the human heart."[3] Delight and the expression of strong emotions was seen in this era as a part of the human condition, and Handel's oratorios fit into the three main compositional styles that had been defined by Charles Avison in his Essay on Musical Expression (1752): the grand or sublime, the beautiful or serene, and the pathetic or devout, plaintive, or sorrowful. In a similar vein, James Beattie observed that "mere descriptions, however beautiful, and moral reflections, however just, become tiresome, where our passions are not occasionally awakened by some event that concerns our fellow-men" (qtd Schmidgall 37). The operas and oratorios of this period can be "read" as a "series of passionate or affective vignettes" which appear to portray the actions and emotions of their characters in a piecemeal fashion. Schmidgall sees Handel as working in the "passion-based aesthetic" of his time. His airs particularly attempt to express idealized versions of one of the passions of the human heart and therefore they reveal the eighteenth-century bias toward generalizing, and one thinks of Joanna Baillie's Plays on the Passions in this context. The Cartesian assumption that passions or emotions are definite in character, concrete in form, and separable in the mind led Shaftesbury to claim that human passions rather than reason were the "springs of action." Shaftesbury attempted then to categorize the passions as "natural or social" affections directed toward the general welfare; "the self or private" affections directed toward the individual's own good; and the "unnatural" affections directed toward neither. In Germany this tendency to systematize led to the theory of Affektenlehre, the doctrine that explained how the passions could be portrayed in music, leading to the belief that dramatic music must deal in various specific human emotions in order to evoke a pathetic response from its audience (Schmidgall 38-9). But this brings us to the Germanic attempt to define "rescue opera," that musical experiment to translate the British gothic sensibility, complete with all its paranoia, claustrophobia, persecution mania, and ambivalence toward authority, onto the opera stage and which probably had its first incarnation in Friedrich von Schiller's 1781 robber rescue drama, Die Raüber.

\section{II: Definitions}

Defining "rescue opera" musicologically and developing a clear and concise history for this genre has been fraught with difficulty. David Charlton has claimed that the term itself is unhistorical and of limited usefulness because it "plays false on three levels [of] the musical theatre that it purports to represent" ("On Redefinitions" 169). First of all, the term does not distinguish between works of different moral purposes or dramatic styles. Secondly, the term relies on a blanket notion of "rescue," but does not take into consideration all of the other moral 
actions involved. Thirdly, the term ignores eighteenth-century definitions of its own theater. In summarizing all of the meanings for the term that have been proposed by musicologists as eminent as Winton Dean et al., Charlton claims that all of these attempts at definition "fail to account for certain operas and tendencies" (“On Redefinitions" 169). For him, rescue operas are not part of what he calls "an authentic genre like 'opera buffa." Instead, the term was coined only in the late nineteenth and early twentieth centuries, as a legacy of that movement that sought to label music by the use of one word (e.g., Humanitätsmelodie). Dyneley Hussey used the term "rescue opera" to describe Beethoven's Fidelio in 1927, while Karl M. Klob labeled these works "das sogenannte Rettungsoder Befreiungsstück," (our translation: "the genre of the so-called rescue or deliverance operas"), suggesting that the term had become useful as a means of connecting the German Fidelio to the French tradition. As Charlton observes, the term "rescue" is problematic in that it suggests a happy resolution, the use of a deus ex machina to resolve complications much in the manner of opera seria.[4] Yet the sudden reversals of fortune which many of the rescue operas stage resemble less the coup de thêatre of classical theater which corresponded to the shifting alliances among royals and more to the "tableau" in which everyone is (re)united in and because of their desire to be happy. For our purposes it might be useful to draw the following analogy: the genre of "opera semiseria" is the musical equivalent of the literary genre of melodrama, while "rescue opera" is the staged correlative of the "roman frénétique/noir" or gothic novel.

Most musicologists agree that Michel-Jean Sedaine (1719-97) was the founder of the rescue opera-melodrama. They cite his very successful Richard coeur-de-lion (1784) as the originator of the genre. Indeed it was in its genre as successful as Beaumarchais' Mariage de Figaro for the 1780s decade.[]] Claiming that he wrote light opéras comiques larmoyants in the Italian style, Sedaine particularly influenced René-Charles Guilbert de Pixérécourt (1773-1844), who in turn recognized his artistic paternity when he stated that melodrama was a "musical drama in which the music is played by the orchestra instead of being sung" (qtd Rahill 18) and was to be known as "l'école de Sedaine perfectionnée" [trans: "the school of Sedaine perfected" (Ledbury 248)].

Sedaine's originality stemmed from his belief that drama should deal with political and moral issues and, in the rescue operas, he explores the theme of "unjust detention." In each case the reasons for detention are different, and even though the plot emphasizes the excitement of the danger and tension found in the actual rescue, the underlying ideology portrayed avoided the simplistic moral categories of the popular melodramas dominating the French stage. The dungeon, which did not originate as a metaphor because of the Bastille, but because of its role in medieval literature, had by then become popular in England with the successes of such gothic novels as The Monk and The Italian. By the mid-eighteenth century, the prison was the trope most frequently referenced in these works, in addition to the imprisonment of the Philosophes for their publications and work on the Encyclopédie, as well as the arbitrary and infamous uses of the lettres de cachet. 
Whereas Richard coeur-de-lion and Le Comte D'Albert (1786) concern the rescue of an aristocrat after violent assaults on prisons and the dramatic collapse of much pasteboard scenery on stage, Le Roi et le fermier (1762), one of many operas Sedaine wrote celebrating "freedom," has the heroine Jenny happily escaping from her abductor. Therein the motif of endangered female innocence and sexual victimization is played out in a spectacularizing manner with the peasant girl, Jenny, cast as the victim of the lust of the aristocrat Lurewel. Although Richard says in Act I, scene iv that she has been "enlevée, séduite, trompée" (trans: "kidnapped, seduced, betrayed"), Lurewel later tells a courtier that "elle fait la sotte,' (trans: "she is acting foolishly") which represents his view (a literary-aristocratic cliché) of her defense of her honor. By having her embody some of the characteristics which patriarchal society desired of the ideal woman at this period ("Ma Jenny est si douce, si timide," Act I , v: trans. "My Jenny is so sweet, so timid"), the libretto sets her up both to validate the patriarchal mode of female subjugation, and to put it into question since she escapes by using her wits (Dunkley 55).[]

\section{1}

By the 1790s rescue operas were extremely popular, both in Britain and France, and adaptations of popular gothic novels about victimization and persecution reached all classes in a variety of theatrical and operatic venues. There were dozens of gothic novels written in England between 1764-1799, a large number of which attempted to defend the increasingly serious threats posed against the monarchy and the aristocracy more generally in England. The gothic began as an ideologically conservative genre committed to shoring up the claims of primogeniture and inheritance by entail. Novels such as Walpole's Castle of Otranto (1765) and Clara Reeve's Old English Baron (1778) were concerned with unjust tyrants, imprisonments, escapes, disinheritances, wrongful claims on an estate, threatened assaults on virginal females, and the eventual triumph of the "true" aristocrat as rightful heir. The staged form of these plots stressed the dramatic effects, and, as the Terror's impact spread, melodramatic villains appeared in increasingly horrific manifestations.

12

The popularity of the gothic as a genre was conveyed almost immediately to France, where translations and stage adaptations of the British novels were in vogue. The first example of a British rescue opera was an adaptation of Sedaine's libretto and André-E.-M.Grétry's musical score for Richard coeur-de-lion, which was staged in London in two different versions in 1786. The most accomplished British musical composer of rescue operas was Stephen Storace, whose popularity was based on such escape operas as The Haunted Tower (1789), The Siege of Belgrade (1791), The Pirates (1792), and Lodoiska (1794). The last work, set in Poland during the Tartar invasion, was adapted as a text by John Philip Kemble for Storace from Kreutzer's French version (1791). Like the others in this genre, it concerns a beautiful Countess imprisoned by an evil Baron and rescued by her beloved Count and his servant, with the unwitting aid of the Tartars (Taylor 94-5). The other dominant example of British rescue/gothic drama was Blue Beard (1798) by the well-known playwright George Colman and the successful singer-composer Michael Kelly. Their collaboration, again adapted from the French Barbe bleue by Grétry (1789), placed Blue Beard in the Orient and relied on references to Napoleon's campaign in Egypt 
(Taylor 113). And if its political insinuations were not potent enough, this time the heroine has to escape from the harem of an accomplished wife-killer (Taylor 113).

\section{3}

It was a short step from the gothic novel to the "rescue opera," with several versions of the same novel often appearing on stage within the same year even. For instance, in 1798, François B. Hoffman and Nicolas Dalayrac adapted Radcliffe's novel The Mysteries of Udolpho (1794) as the "tyrant" rescue opera Léon, ou Le Château de Montenero. And Pixérécourt, dubbed the "Corneille of the Boulevards" because most of his works were played on the boulevards that had replaced the old walls of Paris, turned the same British gothic story into Le Château des Appenins ou le fantôme vivant (1798), transforming as he went the ghostly apparitions of his source into hoaxes perpetuated on the gullible. Other less prominent French melodramatists utilized all the gothic devices at their disposal, hence there were bleeding nuns, doppelgängers, evil Dukes, and eventually vampires all over the French stage. M.-C. Cammaille-Saint-Aubin and César Ribié adapted Lewis's Monk in 1797, causing a sensation and fostering a continuing obsession with the gothic on the Boulevard stage (Rahill 27). Le Moine was so popular that it was performed 116 times at a variety of Parisian theaters, including eighty performances at the Théâtre de la Gaîté.

\section{4}

But notice how rescue/exile/outlaw opera is transformed and anglicized in a typical example of a later native British "comic-opera," Balfe's The Maid of Artois (1836), with libretto by Bunn. The heroine Isolde has been kidnapped by the villainous marquis, while the hero Jules attempts to rescue her, but instead he is captured by the marquis's henchmen and sent to a penal colony in Guiana. During the second act, however, Isolde manages to shake her jailors and travel across the ocean disguised as a sailor. Once safely landed, she then disguises herself as a Sister of Charity and rescues Jules herself. During their daring and dangerous escape, the lovers are rescued yet one more time, now by the reformed and repentant marquis, who begs them for forgiveness so that they can all live happily ever after. The dialogue was spoken and interspersed between the arias, but clearly the genre was infused with melodramatic as well as gothic tropes (and reminds us more than a little of Beethoven's Fidelio). To conclude, the British rescue opera focused on material that was almost uniformly adapted from earlier French operas, but it tended to emphasize gothic elements that its populace would easily recognize from their readings of the novels and their attendance at the gothic dramas that were so quickly staged and based on those novels.

\section{III: French Sources}

\section{5}

It is necessary, therefore, to turn now to the situation in France, as there was as much artistic collaboration between the two countries as there was political angst and economic rivalry. While it is common to claim that the British imported melodrama from France (cf. Brooks) as they had earlier adopted opera from Italy, it is also possible to see a more convoluted pattern of influences 
by shifting our gaze back to the mid-eighteenth-century or so. All sorts of diversions moved across the English Channel in both directions, and there was in Paris a full-blown "cult of all things English" during the mid-eighteenth century (Rahill 109), including such entertainment enterprises as the Vauxhall and the Ranelagh which established themselves in London. The availability of a growing number of translations of fictional and philosophical British and French texts encouraged the exchange of fashionable ideas and an examination of different sources of inspiration. Pixérécourt's favorite reading in 1793, for instance, was Rev. James Hervey's Meditations and Contemplations Among the Tombs (1746-7) and Rev. Edward Young's The Complaint, or Night Thoughts (1742-45), both works typifying what the French referred to as le spleen anglais. As Rahill has noted, the two authors were popular in France because of their "resolute moral didacticism, a morbid preoccupation with grief and misfortune, a noxious and all-pervading sentimentality, and an almost total absence of a sense of humor. All of these were to be in the inheritance of melodrama" (7).

\section{6}

In Paris, during the 1792 theater season, Le Château du diable, a four-act drama by Joseph Loaisel-Tréogate, was a huge success at the Théâtre de la Rue Martin. For many reasons, 1792 marks a turning point in the French Revolution and in the use of political representations and symbols. Along with the proclamation of the First Republic on September 21, the Marseillaise was composed and reached Paris on July 30; the name "Marianne"[7] designated the Republic for the first time and the female figure of Liberty with her phrygian bonnet emblematized the nation; while Louis XVI was imprisoned in August, tried in December and executed on January 20, 1793. Thus the events of 1792 point to gender as a founding category of modern politics, culture and ideology, even though the revolutionary era's gender politics repressed women as subjects - they were excluded from citizenship in June 1793 - and attempted to reconfigure them into subjects of masculine desire. On the theatrical stage, the years leading up to and encompassing the 1789 Revolution realized a transformative shift in the dramatic arts with such works as Jean-Jacques Rousseau's 1775 Pygmalion, Pierre Augustin Caron de Beaumarchais' 1784 Mariage de Figaro, Sedaine's 1784 Richard coeur-de-lion and Pixérécourt's 1800 Coelina ou l'enfant du mystère, which emerged, according to Charles Nodier, as the first representative piece of the "modern" melodramatic genre.[]

\section{7}

Three legal events transformed the French theatrical world during the Revolution. First, actors were granted the status of "citizen" in December 1789; second, in 1790 the Catholic Church, which no longer bestowed legitimacy upon the King, had to swear allegiance to the Republic's constitution; and third, the advent of the 1791 legislation of the National Convention broke up the Comédie française's near monopoly of the repertoire which had limited smaller theaters to productions which differed little from the pantomimic, acrobatic and trained animal entertainment offered at the fairgrounds on the outskirts of Paris. The abolition of state control of theater venues brought about a proliferation of new theaters which rivaled each other in the productions they presented to their newly formed audiences. Spectators were drawn in by the promise that the action would go beyond the excitement and fears of the events witnessed during the Revolution. With the multiple daily beheadings serving as a backdrop to street 
"performances," the excitement on stage had to surpass real disembodiments in order to compete. The boulevard du Temple in particular became popularly and humorously known as the "Boulevard du crime" because of all the staged abductions, murders, rapes and other heinous crimes committed on the theaters's stages.[9] However, the theatrical world's freedom proved to be short-lived. The reign of Terror gradually reinstated modes of censure as certain dramaturges denounced the government's power struggles and, early in the nineteenth century, Napoleon reinstituted the hierarchy of theaters and designated what sorts of spectacles could be performed on the various stages.

\section{8}

The new dramas - most of which changed their categorization (comédie, tragi-comédie, opéra comique, drame, mélodrame etc.) depending often on the venue of the particular performancealluded frequently yet indirectly to current events but in terms of individual stories which were displaced to other locales and times. The plots were borrowed from British successes as well as French literary and feudal histories even as the plays were enrolled by the state to promulgate didactically civic messages of virtue and republicanism. Re-readings of history which conformed (evidently or not) to the principles of the society the Republic was forging underpinned many of the most popular spectacles, while anti-clericalism guaranteed the popularity of a particular entertainment with its portrayal of the abuses perpetrated by convents and cloisters. Thus the ontology of melodrama situates itself within the framework of popular agitation surrounding the abolition of religious orders as well as of slavery, and divorce legislation (Didier 120). After 1789 , operas increasingly took on the characteristics of popular melodrama, with a simple moral structure (the Manichean good vs. evil) and a conclusion that emphasized social and communal freedom rather than personal or individual redemption. The example already mentioned above of Le Château du diable follows this pattern. Consisting of equal parts melodrama and fairy tale, it charts the struggles of a young knight forced to penetrate a perilous castle filled with ghosts, ghouls, and all manner of sensual temptations. After many harrowing adventures endured while surviving his ordeal, the knightly hero learns that his fiancée's father, in fact, has staged all of these horrors, in order to test his loyalty and courage.[10]

\section{9}

Other works attempted to explore regicide and the instability associated with the founding of the French republic. In particular, the recurrent thematics of the imprisonment of women dramatized in different ways the successful and not so effective efforts of the male population to restrain and contain women, especially those of lower social rank who had shown their energy and strength during the period of 1789-1792 by expressing their discontent at the misogynist, racist, and violent injustices of patriarchal society. According to David Charlton, the phases of the French Revolution produced melodrama's thematics in accord with the moment:

The early years, 1789 to 1792, gave rise to works espousing hope in the equality of citizens, hope for constitutional monarchy, and for the self-determining unity of the French nation. The Terror years, 1793-94, produced intense didactic works about sacrifice and patriotism and works 
celebrating military victories. Then the fall of Robespierre (9 Thermidor II/27 July 1794) saw a resurgence of counter-revolutionary movements of all kinds; some contained old fashioned royalists, others, constitutionalists; but they were all united against the memory of Robespierre and his 'drinkers of blood.' (French Opera 9:57)

Encouraged by the success of Le Château du diable, Loaisel-Tréogate went on to write a number of other popular pieces including, for the 1797 theater season, La forêt périlleuse des brigands de la Calabre, one of the most popular melodramas to play nightly to a packed house on the Boulevard du Temple. Over-populated with banditti, the melodrama featured a beautiful heroine, Camille, and her devoted lover, Colisan, struggling against the evil machinations of an outlaw who kidnaps Camille and imprisons her in a cave where he threatens to starve her unless she becomes his mistress.[11] In his attempt to rescue Camille, Colisan stumbles into a secret passageway to the cave and eventually is forced to fight against his own rescuing party since his bandit captors have coerced him to join them. Such melodramatic effects suffusing French popular theater connect these plays with such British gothic novels as Radcliffe's A Sicilian Romance (1790), or to the French roman noir and roman frénétique with their utilization of medieval, chivalric, pantomimic, melodramatic, and gothic conventions.[12]

\section{2}

The popularity of Loaisel-Tréogate's melodramatic pieces rested upon new conceptions of theatrical spectacle largely elaborated by Rousseau, Denis Diderot, Jean-George Noverre, Beaumarchais, and Sedaine which brought together the distinct genres of seventeenth-century classical theater to enact the blurring of their differences. With the politicization of literary and aesthetic criticism in the 1770's, opposition to the Académie's rigidity in differentiating between the genres situated parodic and satirical discourse against a revival of "a formal and civic vocabulary of virtuous emulation" (Ledbury 224) and led to the exploitation of sentiment and emotional anguish, crime and horror on stage. Moving performance style towards pre-romantic topics and conventions, these transfigurations opened the door to melodramatic stagings.

\section{3}

Melodrama, therefore, embodied the desires and expectations of audiences changed by the events of the period in representations of what Nodier called "the morality of the Revolution," including messages about the pathos and appeal of virtue in distress, a scenario which enticed its audience, even if it did so with increasingly convoluted plots. Democratic in their appeal to a variety of spectators, these works advocated standing up to tyrants, traitors, or villains in order to find happiness and respect. Further, in their democratic emphasis, they placed on an equal footing all the arts associated with the theater, including the musical (song and instrumental accompaniment), the corporeal (dance and mime), costuming, stage effects and the decor. Clearly breaking with the normative classical theater elaborated in the seventeenth century, music and pantomime became constitutive staples of French melodrama in large part because of the expressive possibilities of the body. The language of gesture, which Noverre (the "Shakespeare of dance," as David Garrick nicknamed him) observed at fair theaters, as well as 
during his tours at the Garrick theater in London, and which he advocated in his development of the ballet d'action, was presumed universally understandable to a variety of audiences, and thus transferable to other stages. As the performers communicated feelings derived from their moral response to various human conditions, they embodied either concepts of sensibilité which encompassed domestic loyalty, and the work ethic with docile bodies, or absolutist values with satirical moves from heavy conformity to grotesque excesses (Foster 42). Noverre's insistence upon the readability of facial expression extended the melodramatic exploitation of the verbal language's inability to convey the necessary emotion with its alternating use of emphatic music and spoken word.

These physical, visual, and aural complements to the declarative mode of classical theater underscored the emotional intensity of crisis, added legibility to the characters' turmoil and allowed for the body politic, disengaged from the symbolic of the state by the Revolution, to be represented on the stage as actual embodiments of domestic life. The action of the melodramatic plot worked through confrontations having largely to do with questions of identity, misidentification of lineage and social position together with such conflations as that of social rank and the "droit du seigneur" mentality; economic class and male (virtual) blindness; or naïveté (often portrayed by mute male characters) and virtue. Thus although many, including the critics of the time, have emphasized how conservative and simplistic the messages of these melodramas and rescue operas appear, the episodes in the characters' lives and their desires reflect often indirectly and ironically on both the domestic sphere and the political, public arena.

\section{IV: Cross-Cultural Dialogue}

\section{5}

But why did "rescue operas" and their progenitors, gothic melodramas, become so popular before, during, and after the Revolution, and what does such a cultural phenomenon reveal about the vexed and ambivalent cultural relationship between France and England during this period? In our attempt to answer those two questions, we have briefly examined the cultural fluidity of the gothic as a genre and pointed to the increasing interaction between librettists, composers and artists of the two countries who "borrowed" ideas, ideologies, acting styles, and even scripts and libretti from each other. Another important constituent of the genre's success was how audience dynamics impacted and reflected upon the popularity of the genre together with the changing French public which started to resemble the more established British tradition of a diversified audience. With working citizens increasingly attending the theater and with Shakespeare's growing popularity in France, spectators' tastes were altered and this called for a theatrical experience full of emotional appeal and involvement. This new audience was interested in action-packed scenarios (the three unities rule of classical theater forbidding actions on stage clearly did not apply to the melodramatic plots), and rapidly developing intrigues rather than the slow building tableaux that had been popular earlier. Even though some theater critics considered the new theater to be a blatant pandering to the lowest elements, with its heavy reliance on grotesque prison scenes, dramatic escapes, wild crowd scenes, and the simplistic triumph of the just over the unjust, the public that sought entertainment rather than edification nevertheless 
expected to witness recognizable personal experiences which could serve as a means to selfknowledge (Kennedy 19-21).

\section{6}

Rescue operas, therefore, developed along two somewhat different lines: "tyrant" operas and "humanitarian" operas within the general category of "opera semiseria," or "opéra comique." The first type corresponds to the conservative British "loyalty gothic," with its focus on the trials and tribulations of the aristocracy, while the second type draws upon the Sentimental "virtue in distress" or "woman in jeopardy" genre, with its focus on middle class characters or women as the captured or besieged. The first category emphasized political injustice or abstract questions of law and embodied the threat of tyranny in an evil man who imprisons unjustly a noble character. Etienne Méhul's Euphrosine and H.-M. Berton's Les rigueurs du cloître (both 1790) are typical examples of the genre. "Humanitarian" operas, on the other hand, do not depict a tyrant, but instead portray an individual — usually a woman or a worthy bourgeois - who sacrifices everything in order to correct an injustice or to obtain some person's freedom. Dalayrac's Raoul, Sire de Créqui (1789) or Bouilly's and Cherubini's Les deux journées (1800) are examples, along with Sedaine's pre-1789 works. This tendency to depict in grandiose manner an act of humanity ties in with the general mood of the times and figures prominently in all the arts including painting, where such works have been labeled, according to R. Rosenblum, exemplum virtutis. The parallels which Ledbury has examined between the works of Sedaine and the painter Jean-Baptiste Greuze (1725-1805) illustrate this correspondence, while Sedaine's father-like mentoring of David bears witness to the close collaboration that existed between the arts in the staging and representation of ideology.

\section{7}

"Opera semiseria," combining comic and horrible events with both aristocratic and lower-class characters, was well suited to the sentimentality of the period. Ironically, in a manner reminiscent of Sade, these operas specialized in juxtaposing the pathetic with the appalling without having to carry through the action to a tragic conclusion. Ferdinando Paër (1771-1839), an Italian who spent most of his productive life in Germany and France, is remembered today as one of the major practitioners of opera semiseria. One of his most famous operas was Camilla, ossia Il sotterano (1799), whose plot bears an uncanny resemblance to the aforementioned Radcliffe gothic novel, A Sicilian Romance, as can be seen from the brief synopsis of the action, which virtually retells the same story. This semi-serious opera makes heavy use of macabre settings, aberrant psychology, and jarring juxtapositions of the comic with the serious. The heroine Camilla has been imprisoned for seven years when the opera begins, forced to inhabit the underground vaults of a ruined castle in Naples owned by Duke Uberto, her husband by a secret marriage. The reason for Camilla's banishment is provided quickly: she has refused to reveal the identity of a man who once kidnapped and tried to seduce her, albeit unsuccessfully. After much confusion over false identities and forced confessions, Loredano and Cola, the Duke's nephew and servant, rescue Camilla and her son Adolfo. Loredano is himself forced to confess that he was the abductor and he clears Camilla's name so that she can be reconciled to her husband and son. Paër's version of the story utilized the same source as Dalayrac did for his opera of the same 
title (1791). But what is clear from these adaptations of A Sicilian Romance is how quickly British novels made their way onto Parisian stages.

Another example of an opera semiseria by Paër, I Fuorusciti de Firenze (1802), reveals yet another strain of the rescue opera, the "exile" or "outlaw" opera that would become particularly popular by 1830. In this work, the Princess Isabella of Florence has been kidnapped by Uberto's banditti and imprisoned in a ruined Tuscan castle. His inveterate enemy Edoardo de Liggozzi, Isabella's husband, had exiled Uberto himself from Florence twenty years earlier. In the disguise of a shepherd, Edoardo attempts to rescue his wife, but is captured and forced to reveal his true identity. Rather than kill the pair, Uberto suddenly reveals that twenty years earlier he had left an infant daughter in Florence when he was forced into exile: Isabella. As one might expect, a happy ending is provided amid much sudden light relief. Such a work as I Fuorusciti di Firenze reveals how thoroughly the gothic had been sentimentalized or melodramatized by the turn of the century. By then, the use of the reunion between parent and child, a staple of stage melodramas also found in Pixérécourt's Coelina, had infiltrated opera.

But genres do not proliferate out of thin air. They evolve to serve specific ideological purposes, and theorists who have social, political, cultural, and aesthetic agendas in mind construct them. Diderot's dramatic theory inspired the development of the drame bourgeois otherwise known as tragédie bourgeoise/domestique or drame sérieux and it influenced importantly Beaumarchais and Louis-Sébastien Mercier in France and Lessing and the Stürm und Dränger group in Germany.[13] In his Discours sur la poésie dramatique (1758; Discourse on Dramatic Poetry), Diderot distinguishes between "two types of tragedy, tragédie domestique 'qui aurait pour objet la vertu et les devoirs de l'homme' (trans: whose subject would be virtue and man's duties), and tragédie héroïque "qui a pour objet les catastrophes publiques et les malheurs des grands"' (trans: whose subject focused upon public calamities and the misfortunes of the great) (qtd Ledbury 219). His tragédie domestique used "an intense private space to symbolize society" and "never posed the relationship between the private and the public spheres as a problematic one." Many of the issues debated on the literary and philosophical page also applied to the opera stages. Diderot's drame especially influenced opéra comique from the late 1750 s on, and it was this "fertile centre of dramatic experiment" (232-33) in the 1770's which in turn engineered melodrama, or what Peter Brooks calls in The Melodramatic Imagination, a modern cultural discourse.

Theorizing about genre in eighteenth-century France "mutated from a discourse of hierarchy to a discourse of opposition" which associated the notion of genre with that of gender. Where "hierarchical structures of thought and behaviour were central to the mind-set of the court society ... [for] the encyclopédistes and other philosophes from Buffon to Diderot ... the importance of genre and generic categorisation [was] ... key to organising and understanding the complexity of nature and culture.’[14] Innovations which interrogated the hierarchical 
system of genres and the aesthetic culture of the times encountered horror and fascination and the possible creations were denounced as monsters in Claude-Henri Watelet's terms by those working against the new forms. Of course, the figurative monsters so vehemently remonstrated against were soon translated into literally horrifying figures. We would argue, in fact, that the gothic melodramas and the rescue operas were exegeses on the distrust of this very new genre, for they liberalized the fears and the very language used to combat the new genre.

\section{1}

Sedaine, who wrote the libretti for some of the most successful opéras comiques of the last third of the eighteenth century, modernized by hybridizing the genre in such works adapted from British plays as Le Diable à quatre ou la double métamorphose (opéra-comique, 1757), and Le Roi et le fermier.[15] The latter, first performed on November 22, 1762, was based upon Robert Dodsley's The Miller of Mansfield.[16] Sedaine's comedy aspired to a new kind of seriousness with its presentation of an egalitarian storyline. According to Ledbury, the play combines both the intimate sphere and public life; audaciously exploits royal presence; presents the irresistible characters of Betsy and Richard; and implicitly critiques court circles and the abuse of power (100). Act I opens with Richard, the intendant des forêts, worried about Jenny, who has been absent since morning. When she does return, she explains that she has escaped from the castle of Lord Lurewel. However, since her flock, which was lured into the grounds as a device to snare her is still trapped, she now has no dowry and worries that this will prevent her marriage to Richard. In Act II, which takes place in the forest, Richard meets the king, who has been separated from his courtiers and does not reveal his identity. Richard mistrusts him and treats him brusquely at first, but eventually invites him in to shelter from the storm. At the same time, Richard's gamekeepers arrest Lurewel. In Act III, over a joyful supper with the king, Richard tells Jenny's story. Lurewel is brought in, and after the king has revealed his identity, the former is sent away in disgrace and the king offers to resolve all difficulties by providing Jenny's dowry $(100 ; \mathrm{n} 75)$. Thus Jenny, rather than being seduced as she is in the English version, escapes, while the beneficent and wise king, in contact with his people, sees the corruption and injustices of his courtiers and moves to correct and chastise them (102).

\section{2}

Sedaine worked through operatic reformulations with reconstructions of medieval stories such as Aucassin et Nicolette ou les moeurs du bon vieux tem[p]s (comédie, 1780) and Richard coeurde-lion (comédie, 1786). As against Lionnel Gossman's argument that the introduction and use during this period of the medieval was a conservative move, it appears that the rage for medievalism allowed Sedaine and his contemporaries to explore new themes and stage possibilities. It enabled transformations in stage decor and satirical (and ironic) messages to underlie the retelling of narratives like Aucassin et Nicolette. The staging of this anonymous late twelfth or early thirteenth century text, with its own extraordinary (parodic) intertextuality referencing Chrétien de Troyes's romances and earlier chansons de geste, including The Song of Roland and La prise d'Orange, sustains aptly Sedaine's argument in favor of genre hybridity. As chantefable, Aucassin et Nicolette alternated prose and assonanced verse and its performances, which sought to entertain rather than edify and instruct, were most likely musically accompanied. Prefiguring the form of opéra comique by almost six hundred years, the plot of this medieval tale 
anticipates those of the rescue operas. Its intrigue suggests that everything should be subordinated to love, including such chivalric attributes as honor and nobility. Indeed, Aucassin loves Nicolette, although she is a slave who has been baptized and is the godchild of the town's viscount, his father's vassal. His father refuses to let him marry her, however; and the father orders the viscount to send her away. The latter decides instead to seal her in his sumptuous palace. Utilizing both Nicolette's and Aucassin's refusal to obey their parents' wishes with regards to whom they are to marry, as well as keeping the anti-clerical and feminist messages of the medieval version, allowed for a spirited participation in the social and cultural upheavals of the 1780's from within the safe confines of a national literary treasure. This "revival" perhaps more than any other adaptation signals how the use of these medieval texts encouraged change and presented the new parameters of opera performance under the guise of historicity.

\section{3}

Sedaine's 1770 prose tragedy, Maillard ou Paris sauvé, attempted to breach the "natural and immutable barrier between high and low genre" (Ledbury 198). Although the play's nationalism, its historical setting in the fourteenth century, and the entanglement of the domestic and political opposition between Maillard and Etienne Marcel placed it within the tragic mode, the work is clearly a hybrid. Maillard contains several scenes that daringly reveal the intimate relations of the young bourgeois lovers, and the depiction of their child and the mother's breast-feeding pains disturb the bienséances of the genre (200-202). Furthermore, the almost choreographed spectacle, especially during the conspiracy scenes, together with such props as daggers thrust into a table, demonstrate Sedaine's familiarity with the conventions of opera comique and with Shakespearean tragedies. Even Madame du Deffand commented to Walpole after having attended a private reading in 1770 of the first draft of the play that: "Cette pièce a plus de ressemblance à celles de votre Shakespeare qu'aucune des nôtres" [trans: "This play resembles more your Shakespeare's [plays] than any of ours."] (qtd. Ledbury 212).[17] Never publicly performed, Maillard's consignment to obscurity reveals that the limits of tolerance for hybridity were quickly reached. However, the parodies which the Maillard debate fostered proliferated. They demonstrate that the prose tragedy was actually about the threat of genre anarchy (Ledbury 222-23), a literary anarchy which looked to dissolve boundaries and plotted out presciently the course of a civil and egalitarian society.

As a "pre-modern man of the theater," Sedaine did not succeed in breaking the concept of generic purity. However his experimentations, alongside the contemporary discourses as well as the borrowings from Italian and British pantomimic traditions which David Garrick and Noverre so prized (Chéruzel 67-72), generated the foundation for an alternative theatrical practice. Sedaine's theatrical sense and understanding of the necessity of intimacy and for an effet du reel, coupled with irony, "provided a blueprint for those practitioners in theater, art, music-drama who, in the later nineteenth century, were responsible for what we now understand as the transition to modernism" (Ledbury, Michel-Jean Sedaine, 38).[18] 
Beethoven's Fidelio, perhaps the most famous of all the so-called rescue operas, is considered by many to be the final flowering and only masterpiece of the rescue-opera genre. It was based on Jean-Nicolas Bouilly's (1763-1842) libretto and Pierre Gaveaux's score,[19] and their version, an opéra comique, opened at the Théâtre Feydeau on February 19, 1798 as Léonore ou l'amour conjugal. This work was in its turn adapted by Mayr as L'Amour Conjugal (1805) and also by Paër as Leonora (1804). Each version skillfully combined elements of both "tyrant" and "humanitarian" operas. Bouilly's Léonore drew on recent French innovations with the imprisonment topos, the female singer in the male role, and the use of the rescue plot. Performed in the former ultra-royalist but pro-Italian opera Théâtre de Monsieur, with all its attendant social and political reputation, its composer played the role of Florestan, in an intrigue which engaged "French history by dramatizing a political crime at a sensitive juncture in the Directoire (179599)." "[H]istorically self-referential," it showed with very slight disguise "events that had occurred in recent life" (51).[20] The Leonore libretto belongs to the Thermidorean reaction period after the end of the monarchy and of the revolutionary dictatorship (Charlton, French Opera 9:57). Fidelio first played in 1805 as a three act opera entitled Leonore as Napoleon invaded Austria. The 1814 definitive version bore the title of Fidelio and celebrated the triumph of liberty over tyranny and clearly marked Napoleon as the tyrant in Beethoven's eyes, and indeed the rescue opera played over and over again during the Congress of Vienna in 1815.

Originally set in Spain, the story concerns an imprisoned young woman, Leonora, who disguises herself as the boy Fedele. While living in the jail, she apprentices herself to the jailer Rocco, hoping to be able to use her position to free her husband Florestano, unjustly imprisoned for two years by the tyrant Pizzarro because Florestano had exposed the crimes of Pizzarro (and thus made himself a victim of unjust abuse of power). Pizzarro learns that his supervisor, Fernando, will arrive for a visit the next day, and he fears that his treachery will be discovered and punished. In desperation, he commands Rocco to prepare Florestan for his assassination, to be performed by the masked Pizzarro and witnessed by the devoted apprentice Fidele. But Fidele stalls long enough for Fernando to arrive and rescue her husband. Rocco is pardoned, and Pizzarro imprisoned. Even though Bouilly's politics bespoke of liberalism, his Léonore avoided explicit political allegorizing. Structured around motive and incident, it nevertheless portrayed the villain Pizarro as a tyrannical monster. His cruelty, described by a chorus of prisoners in the dungeon, signified by analogy the excesses of 1793-94 rather than any commentary on the ancien régime, while the finale of the spectacle celebrated the return of justice and truth (Charlton, French Opera 9:64-67).

Other works that anticipated Fidelio include Sedaine's Comte d'Albert, and his Le déserteur, which must have influenced Beethoven since it was "the most frequently performed stage work in Germany of any genre” (Charlton, French Opera 9:54-55). Dalayrac's Raoul, Sire de Crequi also prefigured Fidelio politically and dramatically and its English adaptation at the Theatre Royal, Drury Lane in 1792, includes the cross-dressing of two women as soldiers who seek to liberate the brother to one of them. A copy of Paër's score for Leonora, discovered among Beethoven's effects after his death, reveals that he had certainly studied and was influenced by 
Paër's version of the famous tale. In Beethoven's version, however, there are a few changes, most notably in the emphasis on the group rather than the individual rescue of the husband. Again, the hero, Florestan, is captured by the villainous Pizarro and held in a supposedly impregnable dungeon, while Florestan's wife Leonore disguises herself as a boy, as in the British version, in order to rescue her husband. The reconnaissance or reconciliation scene between husband and wife in prison stands as the high point of the work. And the rescuing troops arrive in the nick of time so that all can end happily.

Operas such as Leonore and Fidelio were essentially serious operas with happy endings, opera semiseries. Clearly this genre was popular and played a particularly influential role in reforming notions of exactly what an opera should look and sound like. As Scott Balthazar points out, such operas emphasized continuous action, formal complexity in structure, and a certain amount of dramatic and musical comedy (NGD, 1150). More importantly, however, they were one means by which the tropes of northern Romanticism spread throughout southern Europe. What is perhaps most interesting to the contemporary literary critic, however, is the persistence of a female disguised as a male, or in a variety of androgynous costumes. Such a trope suggests the constructed nature of gender, while also revealing that gender as well as identity are performances to be enacted for a variety of social and political reasons. The female performer was asserting her rights both as an actor/singer/dancer and as a woman in the characters she embodied. Such a position comes close to the depiction of gender and identity in gothic as well as sentimental novels of the period and points to the new feminine symbols associated with "nation" building.

\section{Conclusion}

So finally it is necessary to ask in conclusion, what does it mean that British citizens flocked to a number of forgettable rescue operas before, during, and after the French Revolution? What was at stake in staging and viewing the performances? As we have suggested, the opera and its mutations/manifestations embodied a public space in which French and British citizens could vicariously experience the threats of violent political, social, and cultural revolution. But ultimately, we believe, the rescue operas were radically nationalistic for each nation, even though, ironically, they used the same tropes and told very similar familial and nationalistic scripts. Each country was trying to use the theater and the opera house to impose a form of nationalism on its emerging bourgeois populace. As Gerald Newman observes, Britain sought to see itself and its citizens in national and secular terms rather than in religious or tribal ones during the mideighteenth-century. This shift was made possible, according to Newman, because of cultural rather than political activity, with one of the central figures being the "artist-intellectual," an individual who "both creates and organizes nationalist ideology" (56). A composite figure begins here to emerge: the adaptation and use of Handel as the artist and Shakespeare as the intellectual, a dual presence hovering as protectors over the domesticated landscape of British discourse. Benedict Anderson has also discussed the growth of secularism as allowing for a new sort of "imagined community," a country with a "national imagination" that would replace the religious 
construction of the medieval and renaissance communities $(6 ; 36)$. There is no question that the institutionalization of the popular, hybridized opera during the eighteenth century was a central development in the growth of the new British "national imagination."

In contrast, French nationalism evolved in a radically different manner, with a revolution that accomplished very different ideological work than did the British revolution of the seventeenth century. At the conclusion of their brief experiment with a Commonwealth, the British welcomed back their King on their terms, and the country has not seriously contemplated violent social or political reform since. France's prolonged sojourn in feudalism made for a combustible situation which ignited in 1789 , and created a politically unstable and contested situation for most of the next century. Both countries staged hundreds of rescue operas, read dozens of gothic novels, and schooled themselves in the tenets of secularization, modernization, and nationalism. Taking their inspiration from Northern European sources-Shakespeare, medieval literature and French and British history especially - these texts were written in the uncertainty which defines modernity. Through the rescue trope, they romanced the past, lured in spectators with terrifying scenes and rhetorical turns, even as they hybridized genre and denounced the injustices and arbitrariness of the throne. So great was the appeal of the rescue operas that its cultural residue, sentimentalism and melodrama, remain with us to this day.

\section{Notes}

"But it is not to the orators of the revolution that the Romantics looked for instruction in rhetoric They looked to the revolution itself, to that language made into History, that draws its meaning from events which are declarations. The Terror, as one knows, was not only terrible because of the executions; it was terrible because it proclaimed itself with this capitalization and made Terror the measure of history and the sign of modern times" (Blanchot 520-21, qtd. Lebrun 174; our translation).

\section{$[2]$}

Joseph Addison observed that the "absurdity of opera shows itself at the first sight," while he went on to note that "nothing is capable of being well set to music, that is not nonsense." Samuel Johnson called opera "an exotic and irrational entertainment," while Jonathan Swift spoke of "that unnatural Taste for Italian Music among us, which is wholly unsuitable to our Northern Climate, and the Genius of the People, whereby we are overrun with Italian Effeminacy and Italian Nonsense" (qtd Schmidgall 32-3). 
Contrast this definition of music with that proposed by Claude Levi-Strauss, who claimed that music is primarily an expression of the emotions, while Roland Barthes has stated that music is "inactual," that is, abstract and difficult to speak about because "language is of the order of the general, [while] music is of the order of difference" And in his own meditation about the meaning of opera, W. H. Auden echoes this definition: "Opera in particular is an imitation of human willfulness; it is rooted in the fact that we not only have feelings but insist upon having them at whatever cost to ourselves. Opera, therefore, cannot present character in the novelist's sense of the word, namely, people who are potentially good and bad, active and passive, for music is immediate actuality and neither potentiality nor passivity can live in its presence" (qtd Schmidgall 20). So while Barthes emphasizes the inactual quality of music, Auden asserts the opposite.

\section{$[4]$}

Charlton's valuable essay "On Redefinitions of Rescue Opera" is the best on the subject, and includes six contradictory definitions of the term in an appendix.

\section{$[5]$}

The success of Richard coeur-de-lion raised the opéra-comique to new levels and led to Sedaine's long sought acceptance in the Académie française (Ledbury, Sedaine 284). Beaumarchais and Sedaine became collaborators and the latter advised Beaumarchais on the Mariage de Figaro.

\section{$[6]$}

Naomi Schor states that "French Romanticism, Realism, and Naturalism all draw their impetus from the revolution: nineteenth-century literature in France is a protracted and therapeutic working through of the trauma of regicide and the shock of democratization" (144).

\section{$[7]$}

The first mention of "Marianne" to designate the Republic occurred in an Occitan song by Guillaume Lavabre entitled "La Garisou de Marianno" ["the healing/recovery of Marianne"].

\section{$[8]$}

Pixérécourt's Coelina, generally considered the first melodrama, was based on François-G Ducray-Duminil's extraordinarily popular novel Coelina ou l'enfant du mystère (See Gaspard 128-129). Rahill provides this definition: "Melodrama is a form of dramatic composition in prose partaking of the nature of tragedy, comedy, pantomime, and spectacle, and intended for a popular audience. Primarily concerned with situation and plot, it depends on mimed action extensively and employs a more or less fixed complement of stock characters, the most important of which are a suffering heroine or hero, a persecuting villain, and a benevolent comic. It is conventionally moral and humanitarian in point of view and sentimental and optimistic in temper, concluding its fable happily with virtue rewarded after many trials and vice punished. Characteristically it 
offers elaborate scenic accessories and miscellaneous divertissements and introduces music freely, typically to underscore dramatic effect" (xiv).

See Brooks passim; and Root-Bernstein.

$[10]$

This tale is reminiscent of François Thomas du Fossé's life story as recounted by Helen Maria Williams in her Letters from France ( 8 vols). He is not tested by his lover's father but by his own father, Baron du Fossé, who cannot accept that his heir will marry the daughter of a local farmer and who issues a lettre de cachet with the aim of imprisoning him to prevent the marriage (see Mellor 261-262).

\section{$[11]$}

The name "Camille" begins to function as a talisman from this time forward, with a beautiful, victimized woman named Camille rescued from out of a tunnel in no fewer than four popular "rescue operas" and melodramas of the period: Marsolier's Camille ou le souterrain (1791), Paër's Camilla, ossia Il sotterraneo (1799), Dalayrac's Camille (1791), and Le Sueur's La caverne (1793) Later, the female victim becomes a courtesan and by 1852 Alexandre Dumas fils had composed the first version of his famous La dame aux camélias, adapted yet again toward the end of the century to great acclaim by the American playwright John Wilds as Camille; or, the Fate of a Coquette.

\section{$[12]$}

For the most thorough recent collection of this work, see Hale. The book assembles 24 tales, 19 of which have never been published before in English, and provides Nodier's definition of the frénétiques: "[These writers] flaunt their atheism, madness and despair among the tombstones, exhume the dead in order to terrify the living and torment the imagination with scenes of such horror that it is necessary to look to the terror-ridden dreams of the sick to find a model."

\section{$[13]$}

See Ledbury, Sedaine 3.

\section{$[14]$}

Such theorists as Roger de Piles, Jean-Baptiste Du Bos, Claude-Henri Watelet, and Voltaire associated the notion of genre with that of gender as they recast genre in oppositional terms. The opposition of genres structured eighteenth-century aesthetic debates and disputes such as La Font's attack upon the Académie Royale de Peinture et de Sculpture in the 1740's or the longrunning Italian/French opera dispute (which included the querelle des bouffons). La Font's 
utilized the gender binary to criticize "Boucher's feminised mythologies" and to call for "a male and noble style" (Ledbury, Michel-Jean Sedaine, 14).

\section{$[15]$}

Le Diable à quatre was Sedaine's first drama written for public performance. It was based on the English play The Devil to pay performed at Garrick's theater, and translated in Claude-Pierre Patu's Choix de petites pièces du théâtre anglais (1756) as La boutique du bijoutier (See Ledbury, Sedaine 87-88). Like Marivaux and Beaumarchais, Sedaine utilized carnivalesque role reversals, farcical violence and alluded to contemporary customs, the activities of the aristocracy and satirized the clergy and the legal profession.

$[16]$

Sedaine consulted Patu's Choix de petites pièces and chose the Dodsley play in part because of its success on the British stage as an afterpiece in 1735 (Ledbury, Sedaine 100)

$\lceil 17]$

Maillard was also a transposition of other English models, including the Restoration tragedy Venice preserv'd by Thomas Otway, which had been transposed by La Fosse into Manlius. Both had been used by Voltaire "to discuss tragic modes in drama in France and Britain in his Commentaires sur Corneille" (Ledbury, Sedaine 212-213). Voltaire saw Maillard as "the final culmination of all the trends . . corroding the great traditions of French drama. He was convinced that it would open the floodgates to a form of practice that would destroy existing order" (213). Even Diderot found Maillard, a high tragedy set as an opéra-comique, too much for his taste and Grimm's lack-luster support implies the general loss of support of Sedaine by the philosophes (Ledbury, Sedaine 220).

$[18]$

See Marcoux.

$[19]$

Gaveaux composed the reactionary song of the jeunesse doréeLe réveil du peuple in the 1790s in order to counter the revolutionary Marseillaise.

[20]

See Charlton, French Opera 9:51-67, 170-172.

\section{Works Cited}


Anderson, Benedict. Imagined Communities: Reflections on the Origin and Spread of Nationalism. Rev. ed. London: Verso, 1991.

Backsheider, Paula. Spectacular Politics: Theatrical Power and Mass Culture in Early Modern England. Baltimore: Johns Hopkins UP, 1993.

Balthazar, Scott. "Ferdinando Paër"; "Leonora"; "I Fuorusciti di Firenze"; and "Rescue Opera." In The New Grove Dictionary of Opera [NGD]. Ed. Stanley Sadie. London: Macmillan, 1992. 816-18; 1150; 316; 1293-94.

Bernard-Griffiths, Simone and Jean Sgard, eds. Mélodrames et romans noirs 1750-1890. Toulouse: P U du Mirail, 2000.

Blanchot, Maurice. L'entretien infini. Paris: L'Athenaeum-Gallimard, 1981.

Brooks, Peter. The Melodramatic Imagination. New Haven: Yale UP, 1976.

Charlton, David. “On Redefinitions of Rescue Opera." In Music and the French Revolution. Ed. M. Boyd. Cambridge: Cambridge UP, 1992. 169-188.

-------. French Opera 1730-1830: Meaning and Media. Aldershot: Ashgate, 2000.

Chéruzel, Maurice. “David Garrick 1717-1779 Compagnon et ami de Noverre.” In Jean-George Noverre: Levain de la danse moderne. Cahors: France Quercy, 1994. 67-72.

Cox, Jeffrey. "Romantic Drama and the French Revolution." In Revolution and English

Romanticism. Ed. Keith Hanley and Raman Selden. New York: St. Martin's Press, 1990. 241-60. 
Didier, Béatrice. "Beaumarchais aux origines du mélodrame." In Mélodrames et romans noirs 1750-1890. Eds. Simone Bernard-Griffiths and Jean Sgard. Toulouse: P U du Mirail, 2000. 115126.

Dunkley, John. "The Representation of the Female in the Dramas of Sedaine.” In Michel-Jean Sedaine (1719-1797): Theatre, Opera, Art. Eds. David Charlton and Mark Ledbury. Aldershot, UK: Ashgate, 2000. 52-67.

Foster, Susan Leigh. Choreography and Narrative: Ballet's Staging of Story and Desire. Bloomington: Indiana UP, 1996.

Gaspard, Claire. "Coelina, de Ducray-Duminil à Pixerécourt: à l'aube de la 'littérature industrielle'.” In Mélodrames et romans noirs 1750-1890. Eds. Simone Bernard-Griffiths and Jean Sgard. Toulouse: P U du Mirail, 2000. 125-144.

Hale, Terry. The Dedalus Book of French Horror: The Nineteenth Century. Cambridge: Dedalus, 1998.

Kennedy, Emmet, et al. Theatre, Opera, and Audiences in Revolutionary Paris: Analysis and Repertory. Contributions in Drama and Theatre Studies 62. London: Greenwood Press: 1996.

Lebrun, Annie. Les châteaux de la subversion. Paris: J. J. Pauvert-Garnier Frères, 1982.

Ledbury, Mark. Sedaine, Greuze and the Boundaries of Genre. Studies on Voltaire and the Eighteenth Century 380. Voltaire Foundation, Oxford: 2000.

---. "Sedaine and the Question of Genre." In Michel-Jean Sedaine (1719-1797): Theatre, Opera, Art. Eds. David Charlton and Mark Ledbury. Aldershot, UK: Ashgate, 2000. 13-38. 
Marcoux, J. Paul. “Guilbert de Pixérécourt: the people's conscience.” In Themes in Drama 14: Melodrama. Cambridge: Cambridge UP, 1992. 47-59.

Mellor, Anne K. "English Women Writers and the French Revolution." In Rebel Daughters: Women and the French Revolution. Eds. Melzer, Sara E. and Leslie W. Rabine. Oxford: Oxford UP, 1992. 255-272.

Melzer, Sara E. and Leslie W. Rabine. Eds. Rebel Daughters: Women and the French Revolution. Oxford: Oxford UP, 1992.

Miles, Robert. Gothic Writing 1750-1820: A Genealogy. London: Routledge, 1993.

Noiray, Michel. “L’opéra de la Révolution (1790-1794): Un 'Tapage de Chien'?” In La Carmagnole des Muses: L'Homme de lettres et l'artiste dans la Révolution. Ed. Jean-Claude Bonnet. Paris: Armand Colin, 1988.

Rahill, Frank. The World of Melodrama. University Park: Penn State P, 1967.

Root-Bernstein, Michele. Boulevard Theater and Revolution in Eighteenth-Century Paris. Ann Arbor, MI, 1984.

Rosenblum, R. Transformations in Late Eighteenth-Century Art. Princeton: Princeton UP, 1967.

Schmidgall, Gary. Literature as Opera. New York: Oxford UP, 1977. 
Schor, Naomi. "Triste Amérique: Atala and the Postrevolutionary Construction of Woman." In Rebel Daughters: Women and the French Revolution. Eds. Melzer, Sara E. and Leslie W. Rabine. Oxford: Oxford UP, 1992. 139-156.

Taylor, George. The French Revolution and the London Stage, 1789-1805. Cambridge: Cambridge UP, 2000.

Watt, James. Contesting the Gothic: Fiction, Genre and Cultural Conflict, 1764-1832. Cambridge: Cambridge UP, 1999. DOI:10.1017/CBO9780511484674

White, Hayden. Metahistory. Baltimore: Johns UP, 1973. 